\title{
MEREDUKSI STIGMATISASI MISIOLOGI HANYA UNTUK PEMIMPIN GEREJA SEBAGAI MOTIVASI ORANG PERCAYA UNTUK BERMISI
}

\author{
Oleh: \\ Yonatan Alex Arifianto \\ Sekolah Tinggi Teologi Sangkakala, Salatiga \\ Email: arifianto.alex@sttsangkakala.ac.id
}

\begin{abstract}
ABSTRAK - Kekristenan tidak luput dari mandat Amanat Agung Tuhan Yesus dalam melakukan pekerjaan misi bagi seluruh dunia. Namun banyak orang Kristen dan gereja enggan melakukan pemberitaan kabar keselamatan. Keengganan untuk menyampaikan berita keselamatan mengakibatkan gereja kesulitan dalam menjangkau orang yang belum mengenal Yesus. Tujuan penelitian ini yaitu untuk memberikan pengertian alkitabiah tentang misiologi sehingga dapat mereduksi stigmatisasi dan memunculkan motivasi untuk bermisi. Penelitian ini menggunakan pendekatan kualitatif dengan metode studi literatur. Hasil penelitian yaitu untuk mereduksi stigmatisasi perlu diajarkan kepada orang percaya dengan memperkenalkan: pertama, misiologi dalam Mandat Amanat Agung Tuhan Yesus yang harus dikerjakan walaupun menghadapi tantangan. Kedua, memotivasi orang percaya dengan mengingatkan bahwa mereka adalah kawan sekerja Allah. Ketiga, menyadarkan orang percaya bahwa dalam mengaktualisasi misiologi harus mendapat pimpinan Roh Kudus yang menyertai proses misiologi itu sebagai rencana Tuhan bagi keselamatan manusia.
\end{abstract}

Kata kunci: Mereduksi, Misi, Orang Percaya, Motivasi, Roh Kudus

\begin{abstract}
Christianity does not escape from the mandate of the Great Commission of the Lord Jesus in doing missionary work for the whole world. However, many Christians and churches are reluctant to spread the salvation news. From this reluctance, the church troubled to reaching out to unbeliever's people. This research aims to provide a true and biblical understanding of missiology so as to reduce stigmatization and generate motivation for mission. This research uses qualitative approach with literature studies method. This research concludes that to reduce stigmatization, beliver needs to be taught about three things. First, Missiology in the Great Commission Mandate of the Lord Jesus which must be done even though it faces challenges. Second, belivers need to remind that they are the co-workers with God to motivate them. Third, convince beliver that in actualizing missiology there are guidance from the Holy Spirit through the process as God's plan for human salvation.
\end{abstract}

Keywords: Reducing, Mission, Believers, Motivation, Holy Spirit 


\section{PENDAHULUAN}

Peran gereja dalam misi untuk menjangkau orang yang belum percaya banyak mengalami tantangan baik secara internal maupun eksternal. Peristiwaperistiwa yang terjadi sepanjang perjalanan para martir bagi Kristus sampai saat ini masih dijumpai. Pada masa awal abad pertama, hampir semua rasul dan murid para rasul itu mengalami aniaya karena memberitakan berita tentang Yesus Kristus. ${ }^{1}$ Namun pemberitaan berita tersebut tetap konsisten dan terus diperjuangkan dari awal hingga saat ini. ${ }^{2}$

Pemberitaan kabar keselamatan kerap kali mendapatkan tantangan dan persoalan. Permasalahan ini bertambah rumit karena adanya jemaat yang tidak melaksanakan pemberitaan kabar keselamatan sebagai orang percaya. ${ }^{3}$ Keadaan ini terjadi karena ada kekuatiran dan ketakutan di hati umat Kristiani untuk melakukan tugas ini. ${ }^{4}$ Akibatnya pertumbuhan gereja lamban. ${ }^{5}$ Dan Fakta yang terjadi di lapangan menunjukkan bahwa masih terdapat gereja lokal yang mengalami stagnasi dalam pelayanan pemberitaan kabar keselamatan. ${ }^{6}$

${ }^{1}$ F D Wellem, Hidupku Bagi Kristus (Jakarta: BPK Gunung Mulia, 2005).

${ }^{2}$ Daud Alfons Pandie and Liem Kok Han, "Urgensi Dan Model Penginjilan Di Masa Pandemi Covid-19," LOGIA: Jurnal Teologi

Pentakosta 2, no. 1 (2020): 79-96.

${ }^{3}$ Kejar Hidup Laia, "Pertumbuhan Gereja Dan Penginjilan Di Kepulauan Nias," FIDEI: Jurnal Teologi Sistematika dan Praktika 2, no. 2 (2019): 286-302.

${ }^{4}$ Tri Subekti, "Pemuridan Misioner Dalam Menyiapkan Perluasan Gereja Lokal," EPIGRAPHE: Jurnal Teologi dan Pelayanan Kristiani 3, no. 2 (2019): 157.

${ }^{5}$ Ibid.

${ }^{6}$ Paulus Purwoto and Asih Rachmani Endang Sumiwi, "Pola Manajemen Penginjilan Paulus Menurut Kitab Kisah Para Rasul 9-28," Angelion Jurnal Teologi dan Pendidikan Kristen 1, no. 2 (2020): 113-131.
Di masa sekarang, semakin menipis kerinduan orang percaya untuk melaksanakan mandat amanat Agung. Menganggap tidak penting dalam merespon sebagai tugas yang tertulis untuk dilaksanakan dengan kesungguhan. Namun sebaliknya orang percaya justru sibuk dengan agenda dan persoalan pribadi maupun aktivitas gereja lokal sendiri. ${ }^{7}$ Kesibukan ini membuat orang percaya tidak bersemangat dalam memberitakan kabar keselamatan. Bahkan orang percaya cenderung tidak memprioritaskan tugas ini dan sebagian melupakannya. ${ }^{8}$ Padahal sesungguhnya pemberitaan kabar keselamatan yang melibatkan orang percaya harus menjadi life style dalam menjalani kehidupan. Dan terlebih penting bahwa tidak ada paradigma dan konsep bahwa pemberitaan kabar keselamatan sebagai tugas dan peran yang hanya dilakukan oleh para pemimpin gereja, pendeta, atau pengkhotbah. $^{9}$

Berkaitan dengan topik mereduksi stigmatisasi misiologi pernah diteliti oleh Djuwansah Suhendro P. Stephanus dengan topik artikel penelitiannya adalah mengajarkan pemberitaan kabar keselamatan sebagai gaya hidup orang percaya. $^{10}$ Kesimpulan dari penelitian tersebut adalah bahwa pemberitaan kabar keselamatan sebagai salah satu tugas esensial gereja yang harus menjadi gaya hidup orang percaya. Berdasarkan penelitian tersebut juga ada halhal ternyata masih belum diteliti yaitu yang

\footnotetext{
${ }^{7}$ Handi Irawan, "7 Tantangan Gereja Di Masa Pandemi Covid-19" (Bilangan Research Center, 2020).

${ }^{8}$ Wisnu Prabowo, "Menerapkan Prinsip 2 Timotius 1: 7 Dalam Pelayanan Penginjilan," MAGNUM OPUS: Jurnal Teologi dan Kepemimpinan Kristen 1, no. 1 (2019): 30-45.

${ }^{9}$ Djuwansah Suhendro P Stephanus, "Mengajarkan Penginjilan Sebagai Gaya Hidup Orang Percaya," Redominate 1, no. 1 (2019): 12-22. ${ }^{10}$ Ibid.
} 
diusulkan dalam penelitian ini tentang mereduksi stigmatisasi misiologi hanya untuk pemimpin gereja di implikasikan pada misi yang harus menjadi bagian hidup dan dikerjakan orang percaya. Oleh sebab itu, penelitin ini akan membahas pengertian yang benar dan alkitabiah tentang misiologi sehingga dapat mereduksi stigmatisasi tersebut dan memunculkan motivasi untuk bermisi.

\section{RUMUSAN MASALAH}

Penulis memiliki tujuan memberikan pemahaman kepada orang percaya serta dapat merubah paradigma atau mindset bahwa misiologi adalah tugas dan tanggung jawab orang percaya yang harus dilaksanakan sebagai gaya hidup orang Kristen. Masalah utama dalam artikel ini adalah bagaimana konsep misiologi Yesus bagi orang Kristen dan penerapannya pada masa kini. Harapan penulis adalah pengertian orang percaya yang salah dapat digantikan dengan pengertian yang alkitabiah. Hasil akhir yang diharapkan terjadi adalah orang percaya dapat termotivasi untuk melaksanakan tugas dan tanggung jawab misi. ${ }^{11}$

\section{METODE}

Untuk menjawab pertanyaan bagaimana mereduksi stigmatisasi misiologi hanya untuk pemimpin gereja sebagai motivasi orang percaya untuk menginjil, maka penulis menggunakan metode penelitian studi pustaka dengan pendekatan kualitatif deskriptif, ${ }^{12}$ yang menganalisi

\footnotetext{
${ }^{11}$ Alvin Budiman Kristian, "Pemberitaan Injil Di Tengah Masyarakat Pluralis," Excelsis Deo : Jurnal Teologi, Misiologi, dan Pendidikan 3, no. 2 (2019): 123-132.

${ }^{12}$ Umrati and Hengki Wijaya, Analisis Data Kualitatif Teori Konsep Dalam Penelitian Pendidikan (Sulawesi Selatan: Sekolah Tinggi Theologia Jaffray, 2020).
}

data-data studi pustaka tentang misi yang dimandatkan kepada orang percaya. Dan hal tersebut diinventarisasi baik maknanya maupun konteksnya. Setelah terumuskan konsep pemaparan misiologi bagi orang percaya dan kaitannya dengan mereduksi stigmatisasi maka kemudian hal itu diuraikan untuk memberikan motivasi kepada orang percaya untuk mengaktualisasi pemberitaan kabar keselamatan. Alkitab digunakan sebagai sumber primer dapat ditemukan ayat-ayat yang memuat topik yang ada dalam tema tersebut. Selanjutnya penulis menelusuri sumber-sumber literatur untuk memperkaya enambah penelitian ini.

\section{HASIL DAN PEMBAHASAN}

Keselamatan yang diberikan oleh Yesus melalui karya kematiandan kebangkitan-Nya membawa penebusan dan kehidupan kekal pada manusia. Tuhan Yesus berkehendakn bahwa setiap orang yang sudah menerima keselamatan harus ikut berperan aktif dalam memberitakan keselamatan sebagai bagian dari mengasihi Tuhan dan sesama. Karena hal tersebut terangkum dalam esensi Amanat Agung Tuhan. ${ }^{13}$ Namun realitas menunjukkan bahwa banyak orang percaya atau gereja tidak mengindahkan misi sebagai tugas utama orang percaya. Padahal melalui pemberitaan kabar keselamatan, orang percaya atau gereja diutus untuk mendeklarasikan serta memproklamasikan berita kabar baik. ${ }^{14}$

Kenyataan sebelum pandemi yaitu banyak gereja mengalami penurunan jemaat. $^{15}$ Bahkan ada gereja yang hanya

\footnotetext{
${ }^{13}$ Yakob Tomatala, Penginjilan Masa Kini 1 (Malang: Gandum Mas, 2004).

${ }^{14}$ Daud Alfons, Pandie Nidia, and Lina Ardela, Urgensi Penginjilan Sebagai Tanggung Jawab Gereja, APOLONIUS : Jurnal Teologi Dan Pendidikan Kristen, vol. 1, 2020.

${ }^{15}$ Dorce Sondopen, "Relasi Antara Pemuridan Dan Penginjilan Untuk Pertumbuhan Gereja,"
} 
memiliki jemaat para kaum lanjut usia dan itupun tidak terlalu banyak. ${ }^{16}$ Hal itu menjadi tantangan bagi orang percaya untuk memiliki pengertian yang benar tentang misiologi dalam mandat Amanat Agung.

\section{Perubahan Makna Misiologi}

Misiologi sesungguhnya telah mengalami perubahan makna. Perubahan yang terjadi di sini tentu bukan ke arah yang benar. Perubahan ini telah terjadi dalam kurun waktu yang panjang.

Perubahan makna misiologi pertama terjadi karena pemahaman bahwa tidak semua orang precaya diberikan tanggung jawab menjadi seorang pemberita Kabar Baik. Beberapa orang percaya menganggap bahwa pemberitaan kabar keselamatan tidak bisa dilakukan oleh sembarang orang. Hanya orang-orang yang memiliki karunia khusus yang dapat melakukannya (rasul, rohaniawan). ${ }^{17}$

Pemahaman ini diperparah dengan adanya pemisahan kaum rohaniawan (kaum pelayan) dengan kaum awam (jemaat biasa). Kaum awam hanya berpikir untuk beribadah dan menafkahi kaum rohaniawan dengan persembahan. Bagi mereka, misi dan pemberitaan kabar keselamatan adalah hal rohani yang merupakan kewajiban kaum rohaniawan. Kaum awam enggan untuk turut campur dalam urusan kaum rohaniawan.

Pendapat bahwa misi adalah kewajiban rohaniawan sulit dipatahkan karena ada yang melarang orang awam membaca Alkitab. Alkitab hanya bisa dibaca oleh kaum rohaniawan karena terkait kompetensinya. Kondisi ini membuat kaum awam enggan melakukan hal rohani

Excelsis Deo : Jurnal Teologi, Misiologi dan

Pendidikan 4, no. 1 (2019): 95-105.

${ }^{16}$ Ibid.

${ }^{17}$ Soleman Kawangmani, Makin Berdoa Mantab Bermisi (Surakarta: Yayasan Gamaliel, 2020), 116117. termasuk di dalamnya adalah misi dan pemberitaan kabar keselamatan.

Perubahan makna misiologi kedua adalah menyamakan antara pemberitaan kabar keselamatan dan perbuatan baik. Banyak orang Kristen yang merasa ketika dia sudah melakukan perbuatan baik (seperti mendoakan orang lain, memberi pengemis) sudah melakukan tugas itu. ${ }^{18}$ Akibatnya banyak orang tidak mendengar tentang Yesus.

\section{Misiologi dalam Mandat Amanat Agung Tuhan Yesus}

Misi gereja dan orang percaya dalam pelayanan untuk memberitakan keselamatan tidak bisa dipisahkan dari mandat Amanat Agung yang disampaikan oleh Tuhan Yesus. ${ }^{19}$ Misi adalah pertemuan antara orang percaya yang dipanggil keluar dari kegelapan dengan orang-orang yang jauh dari pengaruh Kabar Baik. ${ }^{20}$ Oleh karena itu gereja harus memiliki Tujuan yang selaras dengan kehendak Allah. Hal ini sangat penting untuk mendorong gereja dapat bertumbuh. ${ }^{21}$ Misi sejatinya adalah rencana Allah dalam mengutus anak-Nya atau peran pentingnya adalah pengutusan pribadi-Nya (Missio Dei) yang bersifat kekal untuk membawa shalom atau kedamaian kepada umat manusia (umat-Nya) dan segenap ciptaan-Nya demi kejayaan, kemuliaan dan

\footnotetext{
${ }^{18}$ Aris Elisa Tembay, "Konsep Penginjilan Dalam Kisah Para Rasul 18:9-10 Sebagai Upaya Revitalisasi Penginjilan," SCRIPTA: Jurnal Teologi dan Pelayanan Kontekstual 3, no. 2 (2018): 155, https://ejournal.stte.ac.id/index.php/scripta/article/ view/52.

${ }^{19}$ Kosma Manurung, "Efektivitas Misi Penginjilan Dalam Meningkatkan Pertumbuhan Gereja," DUNAMIS: Jurnal Teologi dan Pendidikan Kristiani 4, no. 2 (2020): 225-233. ${ }^{20}$ Edmund Woga, Dasar-Dasar Misiologi (Yogyakarta: penerbit Kanisius, 2002). ${ }^{21}$ Rick Warren, The Purpose Driven Church (Malang: Gandum Mas, 2008), 81, n.d.
} 
kerajaan Allah. Misi (mission) adalah tugastugas (missions) yang tugaskan dan diperintahkan oleh Allah kepada seluruh orang percaya untuk menjadi "alat shalomNya kepada manusia dis eluruh dunia. ${ }^{22}$ Pemberitaan kabar keselamatan juga merupakan wujud cinta dan rasa mengasihi orang percaya kepada Tuhannya dan juga dinyatakan bagi sesama umat manusia. ${ }^{23}$ Dan panggilan Allah untuk misi adalah panggilan untuk melayani. ${ }^{24}$

Allah telah merencanakan keterlibatan orang percaya untuk keselamatan orang berdosa. $^{25}$ Senada dengan hal itu J.I. Packer mengatakan bahwa pemberitaan kabar keselamatan adalah pengkomunikasian yang dilakukan gereja atau orang percaya sebagai bagian dari rencana Tuhan untuk menyampaikan pesan atau berita pengampunan Tuhan sang pencipta kepada umat manusia berdosa. ${ }^{26}$ Namun perlu diperhatikan juga bahwa pemberitaan kabar keselamatan tidak dilakukan secara verbal saja. Keteladanan dan sikap hidup yang benar terlibat di dalamnya. ${ }^{27}$

Kata yang digunakan untuk menyatakan tentang pemberitaan kabar keselamatan adalah euangelizo yang berarti mengabarkan kabar yang bagus atau baik.

${ }^{22}$ Yakob Tomatala, Teologi Misi (Jakarta: YT

Leadership Foundation, 2003).

${ }^{23}$ Petronella Nelly Tuhumury and Stefany John Risna Abrahamsz, "MODEL PENGINJILAN

DALAM YOHANES 4:4-42 DAN IMPLEMENTASINYA PADA MASA KINI," Jurnal Jaffray 10, no. 2 (n.d.): 104-139.

${ }^{24}$ J. Andrew Kirk, Apa Itu Misiologi? (Jakarta: BPK Gunung Mulia, 2015).

${ }^{25}$ Listari and Yonatan Alex Arifianto, "PrinsipPrinsip Misi Dari Teks Amanat Agung Bagi Pelaksanaan Misi Gereja Masa Kini," Gracia Deo 3, no. 1 (2020): 42-55.

${ }^{26}$ J.I Packer, Penginjilan Dan Kedaulatan Allah (Surabaya: Momentum, 2003).

${ }^{27}$ David J. Bosch, Tranformasi Misi Kristen, Sejarah Teologi Misi Yang Mengubah Dan Berubah (Jakarta: BPK Gunung Mulia, 2018).
Kata kedua yaitu kerusso memiliki arti menyampaikan pesan atau berkhotbah atau memproklamirkan. Kata ketiga yaitu didasko memiliki arti mengajar dan kata terakhir yaitu martureo memiliki arti yang dapat disamakan dengan bersaksi. ${ }^{28}$ Dengan demikian pemberitaan kabar keselamatan melibatkan banyak kegiatan tidak hanya secara verbal.

Sebagaimana dikatakan oleh Yesus dalam Amanat Agung (Mat. 28:18-20; Mrk. 16:15), misi merupakan suatu tindakan aktif orang percaya dalam menyampaikan kabar baik dan kabar keselamatan kekal yang telah diberikan Yesus bagi manusia. ${ }^{29}$ Adanya pemberitaan kabar keselamatan yang dilakukan para rasul dan jemaat waktu lalu sampai masa kinilah yang membawa dampak mereka yang belum juga bisa memeiliki pengharapan hidup kekal bersama pencipta yaitu Tuhan Yesus Kristus. ${ }^{30}$ Untuk itu pribadi Yesus yang menghidupi ketaatan kepada Bapa dan mengaplikasikan pengajaran dan perintah Allah haruslah menjadi teladan atau pola bagi muridmuridNya dan orang percaya pada masa kini. $^{31}$ Pemberitaan kabar baik harus diteruskan hingga membawa pertumbuhan menuju orang yang percaya kepada

\footnotetext{
${ }^{28}$ Yakob Tomatala, Penginjilan Masa Kini 2 (Malang: Gandung Mas, 2018).

${ }^{29}$ Kalis Stevanus, "Karya Kristus Sebagai Dasar Penginjilan Di Dunia Non-Kristen," Fidei:

Jurnal Teologi Sistematika dan Praktika 3, no. 1 (2020): 1-19.

${ }^{30}$ Dever Mark, Sembilan Tanda Gereja Yang Sehat (Surabaya: Momentum, 2010).

${ }^{31}$ Alfons Renaldo Tampenawas, Erna Ngala, and Maria Taliwuna, "Teladan Tuhan Yesus Menurut Injil Matius Dan Implementasinya Bagi Guru Kristen Masa Kini," EDULEAD: Journal of Christian Education and Leadership 1, no. 2 (2020): 214-231.
} 
kedewasaan penuh dan menjadi serupa dengan Kristus. ${ }^{32}$

\section{Misiologi dan Tantangannya}

Gereja yang stagnan dan tidak dapat bertumbuh memiliki penyebab dan penyebab yang terpenting yaitu gereja dan anggota jemaatnya tidak terbeban memberitakan Kabar Baik dan tidak melakukan perintah Tuhan untuk menjadikan semua bangsa murid-Nya. Dengan alasan klasik yaitu takut tidak diterima apa yang akan disampaikan dan takut mengalami aniaya sehingga memilih untuk bertoleransi dalam hal ini menghargai tanpa menjadi saksi dan berkat lewat pemberitaan kabar keselamtan. Bahkan sampai lupa bahwa hak ini adalah tugas dan mandat utama dari amanat Agung. ${ }^{33}$ Faktor lain karena hal pemberitaan kabar keselamatan tidak dipahami secara benar dalam penerapannya sebagai saksi Kristus. ${ }^{34}$ Selain rasa takut, hal bersaksi juga merupakan pekerjaan yang dapat menghantui dan mengganggu keberadaan sebagian besar umat Kristen baik status, jabatan, usaha dan lainnya. Anggapan lai yaitu bahwa menjadi pelayan misi itu sangat menyusahkan. Susah dalam pengertian bahwa orang yang terlibat dalam misi dibatasi atau dipersulit hak-haknya, akan mengalami banyak kekurangan, sengsara

\footnotetext{
${ }^{32}$ Timotius Haryono and Daniel Fajar Panuntun, "ANDIL PEMURIDAN KONTEKSTUAL YESUS KEPADA PETRUS YAKOBUS DAN YOHANES TERHADAP KETERBUKAAN KONSELING MAHASISWA PADA MASA KINI," Jurnal Gamaliel : Teologi Praktika (2019).

${ }^{33}$ Laia, "Pertumbuhan Gereja Dan Penginjilan Di Kepulauan Nias."

${ }^{34}$ Yonatan Alex Arifianto, Reni Triposa, and Paulus Karaeng Lembongan, "Bible Study of Mission and Discipleship in the Great Commission and Its Implications for Today's Christian Life," Diegesis : Jurnal Teologi 5, no. 2 (2020): 25-42.
}

terlebih menderita sehingga tidak cukup untuk memenuhi diri sendiri atau keluarga. Hal ini menimbulkan ketakutan akan mengalami masa depan yang suram. Pengertian lainnya adalah bahwa menginjil untuk mendirikan gereja baru merupakan pekerjaan sukar, banyak tantangan dan pergumulan yang harus dihadapi. ${ }^{35}$ Sekalipun ada aneka tantangan namun esensi penting bagi gereja dan orang percaya dan harus tetap menjadi prioritas yaitu membawa orang yang belum percaya datang pada Kristus dan menjadikan-Nya sebagai Tuhan dan Juruselamat serta memiliki komitment yang tegas untuk beribadah kepada-Nya. ${ }^{36}$

Petumbuhan kualitas maupun kuantitas dalam pelayanan gereja merupakan keinginan serta tujuan gereja lokal. Banyak cara untuk mencapai tujuan tersebut namun dalam kaitannya sebagai pribadi yang telah menerima keselamatan dan ketundukan akan mandat Amanat Agung, dengan cara memaksimalkan misi pemberitaan Kabar Baik dalam setiap pelayanan yang dilakukan. Aktualisasi dalam pemberitaan Injil harus seturut dengan mandat Tuhan Yesus.(Matius 28:19-20). ${ }^{37}$ Namun fakta sebenarnya yaitu adanya persoalan yang dihadapi orang percaya atau gereja masa kini yaitu lambannya perkembangan gereja secara ekspansif. Karena itu pemimipin rohani dan para pelayan gereja tidak boleh hanya puas dengan konsep pemuridan yang tujuannya diorientasikan kepada kebutuhan pelayanan di dalam gedung gereja lokal saja. Lalu tanpa disadari gereja melupakan atau mengabaikan prinsip utama yaitu mencetak para pemberi Kabar Baik baru yang memiliki dedikasi untuk pergi sebagai duta

\footnotetext{
${ }^{35}$ Subekti, "Pemuridan Misioner Dalam

Menyiapkan Perluasan Gereja Lokal."

${ }^{36}$ George W. Peters, A Biblical Theology of Missions, 2nd ed. (Malang: Gandum Mas, 2020).

${ }^{37}$ Subekti, "Pemuridan Misioner Dalam Menyiapkan Perluasan Gereja Lokal.”
} 
Allah untuk menjadikan segala bangsa menjadi murid-Nya. ${ }^{38}$

Mandat dari Tuhan Yesus Kristus berkaitan tentang berita keselamatan bagi seluruh umat manusia haruslah menjadi tugas yang dikerjakan untuk dipenuhi, walaupun ada persoalan dan hambatan. Hal ini tidak boleh melemahkan bahkan membuat semangat atau motivasi dalam memberitakan Injil menjadi redup. Tantangan dan tekanan yang dihadapai dan dialami seharusnya menjadikan cambuk untuk terus bergantung kepada Tuhan sang Pengutus. Sembari meminta hikmat dari Tuhan untuk mengusahakan ide dan kreativitas dalam pemberitaan Kabar Baik. ${ }^{39}$ Untuk itu gereja dan orang percaya harus tetap menghidupi pemberitaan kabar keselamatan dan menjadikan hal tersebut menjadi gaya hidup semua orang percaya. ${ }^{40}$ Sebab Gereja dan orang percaya harus melakukan tugas amanat agung sesuai dengan Amanat Agung Yesus Kristus. ${ }^{41}$ Dengan pemahaman yang dapat dipertanggungjawabkan dan dapat menyenangkan hati Tuhan, seharusnya berbagai rintangan dan halangan yang dihadapi tidak dapat melemahkan gairah dalam memotivasi diri melihat jiwa-jiwa yang belum mengenal Yesus dapat percaya dan menerima keselamatan. $^{42}$ Karena peran pemberitaan kabar keselamatan yang pertama dan

\footnotetext{
${ }^{38}$ Ibid.

${ }^{39}$ Rinawaty and Hannas, "Menerapkan Model Penginjilan Pada Masa Kini," Kurios (Jurnal Teologi dan Pendidikan Agama Kristen) 5, no. 2 (2019): 175-189.

${ }^{40}$ Stephanus, "Mengajarkan Penginjilan Sebagai Gaya Hidup Orang Percaya."

${ }^{41}$ Susanto Dwiraharjo, "Kajian Eksegetikal Amanat Agung Menurut Matius 28 : 18-20," Jurnal Teologi Gracia Deo 1, no. 2 (2019): 5673.

42 Rinawaty and Hannas, "Menerapkan Model Penginjilan Pada Masa Kini."
}

terutama adalah mewartakan Kabar Baik sebagai objek material misiologi. ${ }^{43}$

Memang banyak yang dapat dilakukan bagi gereja dalam mendatangkan berkat keselamatan bagi banuak orang tetapi konsep yang benar tentang misiologi adalah memperkenalkan penyelamat manusia dari kebinasaan. Pelayanan ini merupakan cara yang efektif untuk meningkatkan partumbuhan gereja. ${ }^{44}$ Namun sejatinya penghambat pertumbuhan gereja ialah dimana gereja atau orang percaya bahkan para pemimpin kerohanian dalam gereja tidak memiliki passion dan juga beban dalam pemberitaan kabar keselamatan maupun pemuridan. Adanya sikap dan kecemasan takut ditolak serta dianiaya menjadi alasan untuk memilih berdiam diri dan mengabaikan misi Allah seharusnya disingkirkan. Dan juga beralasan bahwa keselamatan adalah hak Tuhan lalu memilih untuk toleransi sampai lupa tugas amanat Agung juga harus dikoreksi. ${ }^{45}$ Memang pemberitaan kabar keselamatan mengalami banyak kendala, sehingga kurang bisa dilakukan dengan maksimal tetapi harud tetap dikerjakan. ${ }^{46}$ Karena memang pemberitaan kabar keselamatan sebagai tugas dan kewajiban orang Kristen yang harus diaktualisasikan. ${ }^{47}$ Pemberitaan pesan Tuhan tentang keselamatan merupakan sebuah nilai tanggung jawab, dan ketaatan semua orang percaya kepada Kristus sang pemberi mandat. ${ }^{48}$ Jadi orang percaya wajib

\footnotetext{
${ }^{43}$ Woga, Dasar-Dasar Misiologi.

${ }^{44}$ Manurung, "Efektivitas Misi Penginjilan Dalam Meningkatkan Pertumbuhan Gereja."

${ }^{45}$ Laia, "Pertumbuhan Gereja Dan Penginjilan

Di Kepulauan Nias."

${ }^{46}$ Rinawaty and Hannas, "Menerapkan Model

Penginjilan Pada Masa Kini."

${ }^{47}$ Tumpal H Hutahaean, "Signifikansi

Apologetika Dalam Penginjilan," Stulos 17, no. 1 (2019): 54-74.

${ }^{48}$ Harming Harming, "Metode Penginjilan

Yesus Dalam Injil Yohanes 4:1-42,"
} 
berpikir bahwa pemberitaan kabar keselamatan merupakan menyebarkan pesan keselamatan yang siap atau tidak siap waktunya harus dinyatakan. ${ }^{49}$ Dan memberitakan Yesus yang adalah pembawa shalom kepada manusia seutuhnya juga bagi manusia seutuhnya, ${ }^{50}$ maka apapun tantangan dan rintangan akan menjadi hal biasa untuk dilalui karena sudah memiliki pandangan bahwa keselamatan manusia berdosa menjadi prioritas dan gaya hidup kekristenan.

\section{Mereduksi Stigmatisasi Misiologi}

Pemberitaan Injil merupakan mandat utama bagi setiap orang percaya atau gereja.. ${ }^{51}$ Hal itu menjadi pelayanan mulia yang dipercayakan Tuhan, sebab setiap pelayanan yang besar tersebut mempertemukan manusia pada keselamatan kekal. ${ }^{52}$ Karena tugas pemberita Injil merupakan mandat bagi semua orang percaya tanpa terkecuali hal itu dipertajam oleh pernyataan rasul Paulus dalam Surat I Korintus 9:16 "Bahwa mandat pemberitaan kabar keselamatan itu adalah sebuah kewajiban yang harus dilakukan tanpa ada pilihan atau berkata tidak. ${ }^{53}$ Terlebih juga sebagai pribadi yang menyampaikan kabar baik harus memiliki sikap hidup ataupun gaya hidup yang tidak menjadi batu sandungan.

Evangelikal: Jurnal Teologi Injili dan

Pembinaan Warga Jemaat 1, no. 2 (2017): 162.

${ }^{49}$ Alfons, Nidia, and Ardela, Urgensi

Penginjilan Sebagai Tanggung Jawab Gereja, vol. 1, p. .

${ }^{50}$ Yakob Tomatala, Teologi Kontekstualisasi

(Suatu Pengantar) (Malang: Gandum Mas, 2018).

${ }^{51}$ Tuhumury and Abrahamsz, "MODEL PENGINJILAN DALAM YOHANES 4:4-42 DAN IMPLEMENTASINYA PADA MASA

KINI."

${ }^{52}$ Ibid.

${ }^{53}$ Laia, "Pertumbuhan Gereja Dan Penginjilan Di Kepulauan Nias.”
Pemberitaan kabar keselamatan sebagai life style inilah yang dikehendaki oleh Tuhan bagi orang percaya atau gereja, sebab kehidupan yang penuh dengan kasih terhadap sesama, yaitu orang-orang yang harus mendengar berita besar tentang keselamatan manusia. ${ }^{54}$ Sebab esensi kabar baik yang dimaksudkan adalah berita tentang pribadi Allah dalam Yesus Kristus. ${ }^{55}$

Oleh karena itu untuk dapat mereduksi pengertian orang percaya dalam konsep dan pamahaman yang benar tentang misi bisa dilakukan dalam setiap pesan khotbah yang disampaikan dalam setiap ibadah dan lebih menekankan kepada tindakan yang membawa jemaat merespon untuk mengaplikasikan setiap ajakan bermisi. Gembala atau pemimpin gereja juga harus memiliki program penjangkauan jiwa secara holistik yang menginspirasi jemaat atau orang percaya agar menjadi sadar akan pentingnya keselamatan jiwa-jiwa manusia. Memang terlebih dahulu jemaat harus mengerti konsep karya keselamatan Kristus bagi manusia berdosa. Sebab setelah mereka menerima keselamatan maka proses selanjutnya untuk diajar serta dapat mendedikasikan hidupnya untuk menjadi murid-murid yang taat dalam dan bersemangat memberitakan Kabar Baik yang nantinya akan menghasilkan murid Kristus selanjutnya. ${ }^{56}$

\section{Motivasi Orang Percaya}

Injil bukan menyelesaikan perkaraperkara rohani saja, akan tetapi juga berdampak pada kehidupan social. Karena itulah tugas gereja untuk melakukan tiga hal

\footnotetext{
${ }^{54}$ Stephanus, "Mengajarkan Penginjilan Sebagai Gaya Hidup Orang Percaya."

${ }^{55}$ Rinawaty and Hannas, "Menerapkan Model

Penginjilan Pada Masa Kini."

${ }^{56}$ Patrecia Hutagalung, "Pemuridan Sebagai

Mandat Misi Menurut Matius 28:18-20,"

Pengarah: Jurnal Teologi Kristen 2, no. 1

(2020): 64-76.
} 
penting dalam dunia ini yaitu Marturia, Koinonia, dan Diakonia. ${ }^{57}$ Terlebih ada empat elemen penting tentang pesan dari pemberitaan kabar keselamatan yang harus disampaikan yaitu: Apa yang akan disampaikan sebagai kebenaran dalam pesan mandat tersebut ialah pertama, memberitakan kabar baik tentang Kristus dan salib-Nya; kedua, pesan tentang dosa dan anugerah Allah bagi manusia berdosa; ketiga, tentang kesalahan manusia dan pengampunan ilahi akan dosa manusia; keempat, berita tentang kelahiran baru dan juga hidup baru dalam karunia kuasa Roh Kudus. ${ }^{58}$ Untuk mewujudkan misi-Nya dalam dunia ini, Allah menginginkan kerja sama dan juga membutuhkan peran manusia supaya tidak egois sehingga sumber daya manusia, atau anggota-anggota gereja dapat berpartisipasi dalam mengaktualisasi misi. ${ }^{59}$ Oleh karena itu sikap sebagai orang percaya atau orang percaya dalam hal ini warga gereja hendaklah tetap memiliki hati dan motivasi yang benar untuk memberitakan kabar baik guna membawa manusia berdosa bagi Tuhan Yesus Kristus yang dikerjakan oleh peran kuasa Roh Kudus yang memberikan kekuatan untuk terus antusias dan bergairah dalam mengaktualisasi berita keselamatan ${ }^{60}$

Motivasi dalam melakukan misi adalah hal penting dalam aplikasi pelaksanaan mandat misi yang merupakan tanggung jawab yang dimandatkan oleh pribadi Allah kepada seluruh orang percaya. ${ }^{61}$ Tidak dapat

\footnotetext{
${ }^{57}$ Aris Elisa Tembay and others, "Merajut Anugerah Dalam Penginjilan Holistik," SCRIPTA: Jurnal Teologi dan Pelayanan Kontekstual 7, no. 1 (2019): 33-49.

${ }^{58}$ Packer, Penginjilan Dan Kedaulatan Allah.

${ }^{59}$ Kees de Jong, "Misiologi Dari Perspektif

Teologi Kontekstual," Gema Teologi 31, no. 1 (2007): 1-11.

${ }^{60}$ Rinawaty and Hannas, "Menerapkan Model Penginjilan Pada Masa Kini."

${ }^{61}$ Seri Damarwanti, "Pandangan Rasul Paulus Tentang Jembatan Pengantar Injil. Kajian
}

dipungkiri terkadang ada aspek lain yang mempengaruhi dan mendorong orang percaya untuk melakukan pemberitaan kabar keselamatan seperti perasaan berhutang kepada Tuhan karena keselamatan yang diterimanya. ${ }^{62}$ Ini menjadi semangat yang besar untuk memotivasi dalam penyampaian Injil kepada orang-orang yang belum percaya Kristus. ${ }^{63}$ Namun semangat dalam pemberitaan Kabar Baik juga harus termotivasi dari keyakinan dalam pengakuan iman Kristen bahwa Yesus Kristus adalah Allah dan pribadi yang didaulat membawa keselamatan bagi manusia berdosa. ${ }^{64}$ Dengan motivasi tersebut peran pemberitaan kabar keselamatan wajib menanggung tugas memberitakan Yesus Kristus secara utuh, ${ }^{65}$ dan meluas kepada setiap orang yang belum mengenal keselamatan. Karena Kabar Baik tidak boleh dibatasi, tetapi harus diberitakan secara bebas ke seluruh dunia. ${ }^{66}$

Tomatala mengungkapakan bahwa ada peran dan tugas serta tanggung jawab yang wajib dikerjakan oleh orang percaya yaitu umat Allah sebagai pelaku mandat Amanat Agung. Untuk itu pemberitaan Injil harus dinyatakan dalam sikap berikut ini. Satu, pemberitaan Kabar Baik adalah kewajiban yang harus dipenuhi dan beban yang harus dilunasi secara tuntas (Roma 1:

\footnotetext{
Misiologi Terhadap I Korintus 9:1-23," SANCTUM DOMINE: JURNAL TEOLOGI (2020).

${ }^{62}$ Stephen Tong, Teologi Penginjilan (Surabaya: Momentum, 2004).

${ }^{63}$ Manurung, "Efektivitas Misi Penginjilan Dalam Meningkatkan Pertumbuhan Gereja."

${ }^{64}$ Yonatan Alex Arifianto and Ferry Purnama, "Misiologi Dalam Kisah Para Rasul 13 : 47 Sebagai Motivasi Penginjilan Masa Kini," KHARISMA: Jurnal Ilmiah Teologi 1, no. 2 (2020): 117-134.

${ }^{65}$ Tomatala, Penginjilan Masa Kini 2.

${ }^{66}$ Norman E. Thomas, Teks-Teks Klasik Tetang Misi Dan Kekristenan Sedunia, 6th ed. (Jakarta: BPK Gunung Mulia, 2019).
} 
14-15). Dua, Pemberitaan kabar keselamatan adalah tanggung jawab yang harus dilaksanakan dengan dedikasi demi keselamatan orang lain (crucial need). Ini memiliki arti bahwa pemberitaan kabar keselamatan adalah tugas mulia. Tiga, Pemberitaan kabar keselamatan adalah tugas pendamaian sebab penginjil adalah duta atau mediator untuk mendamaikan manusia dengan Allah. Serta yang keempat, bahwa pemberitaan Injil membutuhkan kesigapan umat manusia untuk melakukan tugas setiap hari. ${ }^{67}$ Sebab di dalam pesan Kabar Baik ada informasi yang perlu dipahami dan diketahui manusia. Sehingga hal itu menjadi pernyataan-pernyataan yang akan menolong dan memberkati mereka yang bersedia mendengarkan dan menerimanya. ${ }^{68}$

\section{Aktualisasi Misiologi dalam Pimpinan Roh Kudus}

Orang Percaya diharapkan untuk memperlangkapi diri menjadi pemberita Kabar Baik dengan cara memiliki pengetahuan namun juga bukan saja hanya mengerti akan esensi dari pesan Injil, tetapi orang percaya juga harus menghidupi kebenaran dari Injil tersebut. ${ }^{69}$ Serta hidup dalam pimpinan Roh Kudus, Karena peran Roh Kudus juga memberikan kedamaian, ketenangan di saat orang percaya menghadapi rintangan dan permasalahan, serta Roh Kudus juga pasti meluputkan dari setiap ancaman bahaya. ${ }^{70}$ Roh Kudus yang disebut Roh Kebenaran akan menjadi pribadi yang selalu menolong. Pribadi itu dinyatakan oleh

${ }^{67}$ Yakob Tomatala, Penginjilan Masa Kini Jilid I (Malang: Gandum Mas, 2004).

${ }^{68}$ Charles H. Spurgeon, Strategi Jitu Untuk Menjadi Pemenang Jiwa (Yogyakarta: Penerbit ANDI, 2019).

${ }^{69}$ Hutahaean, "Signifikansi Apologetika Dalam Penginjilan."

${ }^{70}$ Simon, "Peran Roh Kudus Bagi Hamba Tuhan Dalam Merintis Gereja," LOGIA: Jurnal Teologi Pentakosta 1, no. 2 (2020): 41-64.
Tuhan Yesus adalah Pribadi yang akan membawa orang-orang dalam kebenaran, dan terlebih untuk mengenal Yesus sebagai Tuhan dan Juru selamat. ${ }^{71}$ Untuk itu misi bagi orang percaya adalah pergi keluar dari zona nyamannya dan melakukan pemberitaan kabar keselamatan untuk membawa manusia berdosa kepada Kristus. $^{72}$ Pemberitaan Injil juga disebut memberitakan suatu kabar sukacita atau kabar baik, karena kabar tersebut tidak hanya didasarkan pada esensi dari agama Kristen semata namun juga mengandung kebenaran akan nilai-nilai Kristen yang bersifat universal, yaitu cinta kasih. ${ }^{73}$

Pemberitaan kabar keselamatan yang sejati tidak luput dari berita penting yang mengacu pada kabar baik tentang keselamatan dalam Yesus Kristus. Dari kabar tersebut dapat membawa orang untuk datang kepada Yesus sesuai Amanat Agung dalam Matius 28:19-20. ${ }^{74}$ Sejatinya kehendak Allah dalam pemberitaan kabar keselamatan adalah Allah sangat mengasihi manusia berdosa dan menghendaki semua manusia berdosa tersebut diselamatkan. ${ }^{75}$

${ }^{71}$ Yonatan Alex Arifianto and Asih sumiwi Rachmani, "Peran Roh Kudus Dalam Menuntun Orang Percaya Kepada Seluruh Kebenaran Berdasarkan Yohanes 16: 13," Jurnal Diegesis 3, no. 1 (2020): 1-12.

${ }^{72}$ Nugroho Andreas E and Jessica E Chen, "Mandat Ilahi Dalam Peran Sosial Budaya Bagi Penginjilan Di Thailand," THE WAY Jurnal Teologi dan Kependidikan 5, no. 2 (2019): 113124.

${ }^{73}$ WIROL HAURISSA, "Puisi Sebagai Media Penginjilan," KENOSIS: Jurnal Kajian Teologi 4, no. 1 (2018): 73-106.

${ }^{74}$ Stephanus, "Mengajarkan Penginjilan Sebagai Gaya Hidup Orang Percaya."

${ }^{75}$ Soleman Kawangmani, "POLA APOLOGETIKA KONTEKSTUAL UNTUK MEMBERITAKAN KABAR BAIK KEPADA SUKU JAWA WONG CILIK," Jurnal Gamaliel: Teologi Praktika 1, no. 2 (2019): 278-279, http://jurnal.stt- 
Dengan mempercayai bahwa ada Tuhan yang menyertai dalam pemberitaan Kabar Baik dimanapun berada dan kapanpun. Dasar inilah yang menjadi semangat bagi orang percaya untuk terus melakukan tugasnya serta membawa kehidupannnya dalam pimpinan Roh Kudus sebagai bagian ketergantungan orang percaya masa kini dalam melakukan misi bagi dunia. ${ }^{76}$ Untuk itu dibutuhkan panggilan dan komitmen pemberita Baik terlebih dahulu dan harus mengalami terlebih dahulu akan kehadiran Tuhan lewat perjumpaan dengan Pribadi Allah yaitu Yesus Kristus, sebelum menjadi saksi bagi Kristus dan menjadi berkat bagi sesama manusia. ${ }^{77}$ Dengan kekuatan Roh Kudus dan pimpinan-Nya maka orang percaya dapat mengimplementasikan setiap hidupnya sebagai saksi. Namun yang terpenting bahwa orang percaya dapat menuntun dan mendorong setiap jemaat untuk tekun dalam menyampaikan pesan Tuhan tentang keselamatan yaitu Kabar Baik sebagai life style dalam berbagai konteks kehidupan. ${ }^{78}$ Sebab orang percaya harus hadir ditengah-tengah masyarakat dan menjadi pembawa damai dan pemberita kebenaran serta menjadi saksi yang hidup bagi sesama. ${ }^{79}$ Seperti yang diharapkan oleh

gamaliel.ac.id/index.php/gamaliel/article/view/4 0 .

${ }^{76}$ Paulus Purwoto, "Makna Proselitisasi Di Masa Intertestamental Bagi Misi," EPIGRAPHE:

Jurnal Teologi dan Pelayanan Kristiani 4, no. 2 (November 2020).

77 Tuhumury and Abrahamsz, "MODEL PENGINJILAN DALAM YOHANES 4:4-42 DAN IMPLEMENTASINYA PADA MASA KINI."

${ }^{78}$ Stephanus, "Mengajarkan Penginjilan Sebagai Gaya Hidup Orang Percaya."

${ }^{79}$ Yulia Citra and Lenda Dabora J F Sagala, "Penginjilan Dan Pendidikan Agama Kristen Dalam Masyarakat Majemuk," in Prosiding Seminar Nasional Pendidikan Agama Kristen STT Simpson Tahun 2016 Tema: Strategi Pembinaan Jemaat Untuk Meningkatkan
Yesus orang percaya harus menjadi terang dan garam serta kesaksian yang dapat memuliakan Bapa. Harapan Yesus tersebut seharusnya menjadi contoh yang positif dan teladan bagi orang percaya tentang bagaimana pemberitaan kabar keselamatan menjadi gaya hidup-Nya.

Hal itu juga didasari teladan Yesus bahwa dimanapun Ia berada selalu memberitakan Kabar baik, ${ }^{80}$ sehingga orang percaya memiliki fokus dan tujuan utamanya yaitu pemberitaan kabar keselamatan. ${ }^{81}$

\section{KESIMPULAN}

Anggapan bahwa pemberitaan kabar keselamatan adalah tugas dan bagian para pemimpin gereja akan membawa dampak dan konsep misi yang salah bagi orang percaya, sehingga tidak menjadi prioritas atau tidak memiliki beban dalam menjalankan perintah Tuhan tersebut. Untuk itu perlu mereduksi stigmatisasi pemahaman bagi orang percaya dalam misiologi sehingga memunculkan motivasi dan semangat orang percaya untuk memberitakan Kabar Baik.

Dengan demikian dapat disimpulkan bahwa, mereduksi stigmatisasi dalam merubah pandangan tentang tugas misi dapat dilakukan secara aktif dalam berbagai khotbah maupun pengajaran yang bertujuan mendidik orang termotivasi untuk memberitakan Kabar Baik. Hal itu perlu di ajarkan kepada orang percaya dengan memperkenalkan yang pertama, Misiologi dalam Mandat Amanat Agung Tuhan Yesus yang harus dikerjakan walaupun menghadapi tantangan namun motivasi pemberitaan kabar keselamatan bagi orang percaya harus

Kehidupan Jemaat (Ungaran: STT Simpson, 2016).

${ }^{80}$ Stephanus, "Mengajarkan Penginjilan Sebagai

Gaya Hidup Orang Percaya."

${ }^{81}$ Laia, "Pertumbuhan Gereja Dan Penginjilan

Di Kepulauan Nias." 
dikerjakan sebab hal itu adalah bagian dari orang percaya secara personal maupun korporat sebagai kawan sekerja Allah. Namun dalam mengaktualisasi misiologi harus mendapat pimpinan Roh Kudus yang menyertai proses misiologi itu sebagai rencana Tuhan bagi keselamatan manusia.

\section{REFERENSI}

Alfons, Daud, Pandie Nidia, and Lina Ardela. Urgensi Penginjilan Sebagai Tanggung Jawab Gereja. APOLONIUS : Jurnal Teologi Dan Pendidikan Kristen. Vol. 1, 2020.

Arifianto, Yonatan Alex, and Ferry Purnama. "Misiologi Dalam Kisah Para Rasul 13 : 47 Sebagai Motivasi Penginjilan Masa Kini." KHARISMA: Jurnal Ilmiah Teologi 1, no. 2 (2020): 117-134.

Arifianto, Yonatan Alex, and Asih sumiwi Rachmani. "Peran Roh Kudus Dalam Menuntun Orang Percaya Kepada Seluruh Kebenaran Berdasarkan Yohanes 16: 13." Jurnal Diegesis 3, no. 1 (2020): 1-12.

Arifianto, Yonatan Alex, Reni Triposa, and Paulus Karaeng Lembongan. "Bible Study of Mission and Discipleship in the Great Commission and Its Implications for Today's Christian Life." Diegesis : Jurnal Teologi 5, no. 2 (2020): 25-42.

Bosch, David J. Tranformasi Misi Kristen, Sejarah Teologi Misi Yang Mengubah Dan Berubah. Jakarta: BPK Gunung Mulia, 2018.

Citra, Yulia, and Lenda Dabora J F Sagala. "Penginjilan Dan Pendidikan Agama Kristen Dalam Masyarakat Majemuk." In Prosiding Seminar Nasional Pendidikan Agama Kristen STT Simpson Tahun 2016 Tema: Strategi Pembinaan Jemaat Untuk
Meningkatkan Kehidupan Jemaat.

Ungaran: STT Simpson, 2016.

Damarwanti, Seri. "Pandangan Rasul Paulus

Tentang Jembatan Pengantar Injil.

Kajian Misiologi Terhadap I Korintus

9:1-23." SANCTUM DOMINE:

JURNAL TEOLOGI (2020).

Dever Mark. Sembilan Tanda Gereja Yang

Sehat. Surabaya: Momentum, 2010.

Dwiraharjo, Susanto. "Kajian Eksegetikal

Amanat Agung Menurut Matius 28 :

18-20." Jurnal Teologi Gracia Deo 1, no. 2 (2019): 56-73.

Elisa Tembay, Aris. “Konsep Penginjilan

Dalam Kisah Para Rasul 18:9-10

Sebagai Upaya Revitalisasi

Penginjilan." SCRIPTA: Jurnal Teologi

dan Pelayanan Kontekstual 3, no. 2

(2018): 153-171.

https://ejournal.stte.ac.id/index.php/scri pta/article/view/52.

Harming, Harming. "Metode Penginjilan Yesus Dalam Injil Yohanes 4:1-42." Evangelikal: Jurnal Teologi Injili dan Pembinaan Warga Jemaat 1, no. 2 (2017): 162.

Haryono, Timotius, and Daniel Fajar

Panuntun. "ANDIL PEMURIDAN

KONTEKSTUAL YESUS KEPADA

PETRUS YAKOBUS DAN

YOHANES TERHADAP

KETERBUKAAN KONSELING MAHASISWA PADA MASA KINI."

Jurnal Gamaliel : Teologi Praktika (2019).

HAURISSA, WIROL. "Puisi Sebagai Media Penginjilan.” KENOSIS: Jurnal Kajian Teologi 4, no. 1 (2018): 73-106.

Hutagalung, Patrecia. "Pemuridan Sebagai Mandat Misi Menurut Matius 28:1820." Pengarah: Jurnal Teologi Kristen 2, no. 1 (2020): 64-76.

Hutahaean, Tumpal H. "Signifikansi Apologetika Dalam Penginjilan."

Stulos 17, no. 1 (2019): 54-74. Irawan, Handi. "7 Tantangan Gereja Di 
Masa Pandemi Covid-19.” Bilangan

Research Center, 2020.

Jong, Kees de. "Misiologi Dari Perspektif

Teologi Kontekstual." Gema Teologi

31, no. 1 (2007): 1-11.

Kawangmani, Soleman. Makin Berdoa

Mantab Bermisi. Surakarta: Yayasan

Gamaliel, 2020.

. "POLA APOLOGETIKA

KONTEKSTUAL UNTUK

MEMBERITAKAN KABAR BAIK

KEPADA SUKU JAWA WONG

CILIK." Jurnal Gamaliel : Teologi

Praktika 1, no. 2 (2019): 278-279.

http://jurnal.stt-

gamaliel.ac.id/index.php/gamaliel/articl e/view/40.

Kirk, J. Andrew. Apa Itu Misiologi? Jakarta: BPK Gunung Mulia, 2015.

Kristian, Alvin Budiman. "Pemberitaan Injil

Di Tengah Masyarakat Pluralis."

Excelsis Deo : Jurnal Teologi,

Misiologi, dan Pendidikan 3, no. 2

(2019): 123-132.

Laia, Kejar Hidup. "Pertumbuhan Gereja

Dan Penginjilan Di Kepulauan Nias."

FIDEI: Jurnal Teologi Sistematika dan

Praktika 2, no. 2 (2019): 286-302.

Listari, and Yonatan Alex Arifianto.

"Prinsip-Prinsip Misi Dari Teks

Amanat Agung Bagi Pelaksanaan Misi

Gereja Masa Kini." Gracia Deo 3, no.

1 (2020): 42-55.

Manurung, Kosma. "Efektivitas Misi

Penginjilan Dalam Meningkatkan

Pertumbuhan Gereja." DUNAMIS:

Jurnal Teologi dan Pendidikan

Kristiani 4, no. 2 (2020): 225-233.

Nugroho Andreas E, and Jessica E Chen.

"Mandat Ilahi Dalam Peran Sosial

Budaya Bagi Penginjilan Di Thailand."

THE WAY Jurnal Teologi dan

Kependidikan 5, no. 2 (2019): 113-124.

Packer, J.I. Penginjilan Dan Kedaulatan

Allah. Surabaya: Momentum, 2003.

Pandie, Daud Alfons, and Liem Kok Han.
"Urgensi Dan Model Penginjilan Di

Masa Pandemi Covid-19." LOGIA:

Jurnal Teologi Pentakosta 2, no. 1 (2020): 79-96.

Peters, George W. A Biblical Theology of Missions. 2nd ed. Malang: Gandum Mas, 2020.

Prabowo, Wisnu. "Menerapkan Prinsip 2

Timotius 1: 7 Dalam Pelayanan

Penginjilan." MAGNUM OPUS: Jurnal

Teologi dan Kepemimpinan Kristen 1, no. 1 (2019): 30-45.

Purwoto, Paulus. "Makna Proselitisasi Di Masa Intertestamental Bagi Misi." EPIGRAPHE: Jurnal Teologi dan Pelayanan Kristiani 4, no. 2

(November 2020).

Purwoto, Paulus, and Asih Rachmani Endang Sumiwi. "Pola Manajemen Penginjilan Paulus Menurut Kitab Kisah Para Rasul 9-28.” Angelion Jurnal Teologi dan Pendidikan Kristen 1, no. 2 (2020): 113-131.

Rinawaty, and Hannas. "Menerapkan Model Penginjilan Pada Masa Kini.” Kurios (Jurnal Teologi dan Pendidikan Agama Kristen) 5, no. 2 (2019): 175-189.

Simon. "Peran Roh Kudus Bagi Hamba Tuhan Dalam Merintis Gereja." LOGIA: Jurnal Teologi Pentakosta 1, no. 2 (2020): 41-64.

Sondopen, Dorce. "Relasi Antara Pemuridan Dan Penginjilan Untuk Pertumbuhan Gereja." Excelsis Deo : Jurnal Teologi, Misiologi dan Pendidikan 4, no. 1 (2019): 95-105.

Spurgeon, Charles H. Strategi Jitu Untuk Menjadi Pemenang Jiwa. Yogyakarta: Penerbit ANDI, 2019.

Stephanus, Djuwansah Suhendro P. "Mengajarkan Penginjilan Sebagai Gaya Hidup Orang Percaya."

Redominate 1, no. 1 (2019): 12-22. Stevanus, Kalis. "Karya Kristus Sebagai Dasar Penginjilan Di Dunia NonKristen." Fidei: Jurnal Teologi 
Sistematika dan Praktika 3, no. 1 (2020): 1-19.

Subekti, Tri. "Pemuridan Misioner Dalam Menyiapkan Perluasan Gereja Lokal." EPIGRAPHE: Jurnal Teologi dan Pelayanan Kristiani 3, no. 2 (2019): 157.

Tampenawas, Alfons Renaldo, Erna Ngala, and Maria Taliwuna. "Teladan Tuhan Yesus Menurut Injil Matius Dan Implementasinya Bagi Guru Kristen Masa Kini." EDULEAD: Journal of Christian Education and Leadership 1, no. 2 (2020): 214-231.

Tembay, Aris Elisa, and others. "Merajut Anugerah Dalam Penginjilan Holistik." SCRIPTA: Jurnal Teologi dan

Pelayanan Kontekstual 7, no. 1 (2019): 33-49.

Thomas, Norman E. Teks-Teks Klasik

Tetang Misi Dan Kekristenan Sedunia. 6th ed. Jakarta: BPK Gunung Mulia, 2019.

Tomatala, Yakob. Penginjilan Masa Kini 1. Malang: Gandum Mas, 2004. - Penginjilan Masa Kini 2. Malang: Gandung Mas, 2018.

_. Penginjilan Masa Kini Jilid I. Malang: Gandum Mas, 2004.

—. Teologi Kontekstualisasi (Suatu Pengantar). Malang: Gandum Mas, 2018.

- Teologi Misi. Jakarta: YT Leadership Foundation, 2003.

Tong, Stephen. Teologi Penginjilan. Surabaya: Momentum, 2004.

Tuhumury, Petronella Nelly, and Stefany John Risna Abrahamsz. "MODEL PENGINJILAN DALAM YOHANES 4:4-42 DAN IMPLEMENTASINYA PADA MASA KINI." Jurnal Jaffray 10, no. 2 (n.d.): 104-139.

Umrati, and Hengki Wijaya. Analisis Data Kualitatif Teori Konsep Dalam Penelitian Pendidikan. Sulawesi Selatan: Sekolah Tinggi Theologia
Jaffray, 2020.

Warren, Rick. The Purpose Driven Church (Malang: Gandum Mas, 2008), 81, n.d. Wellem, F D. Hidupku Bagi Kristus. Jakarta: BPK Gunung Mulia, 2005. Woga, Edmund. Dasar-Dasar Misiologi. Yogyakarta: penerbit Kanisius, 2002. 